\title{
Presenting 'Lodho Ayam Kampung' as Gastronomic Tourism Attraction in Trenggalek Regency, East Java Province of Indonesia
}

\author{
Andrea Basworo Palestho ${ }^{1}$ \\ 'Ambarrukmo Tourism Institute, Jl. Ahmad Yani Jl. Ringroad Timur No.52, Pelem \\ Mulong, Banguntapan, Kec. Banguntapan, Bantul, Daerah Istimewa Yogyakarta, \\ Indonesia
}

*Corresponding Author. E-mail: palestho.research@gmail.com (Andrea Basworo Palestho)

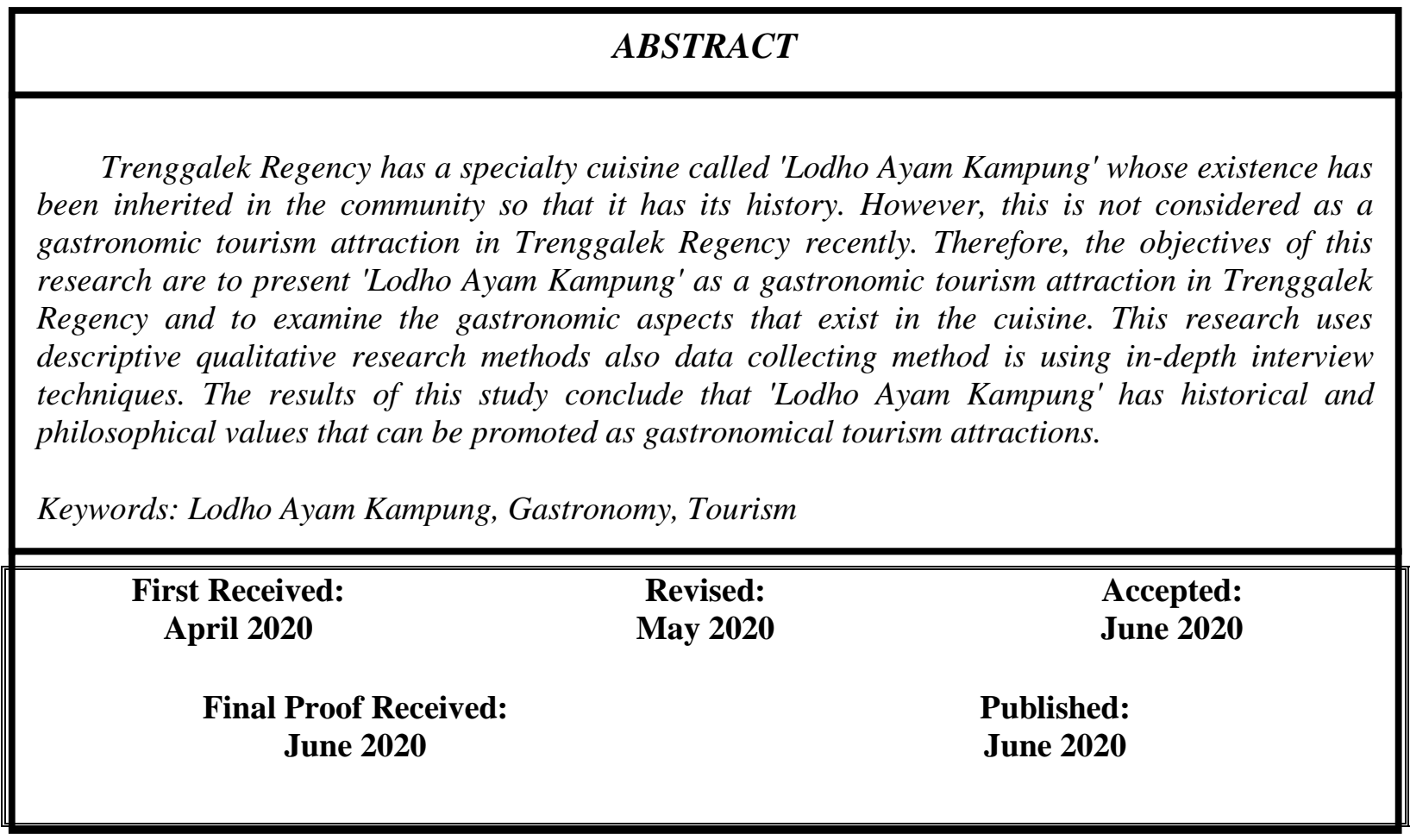




\section{Introduction}

Recently, the role of gastronomy in the tourism industry cannot be ignored, as so regarding the issue of the development of a destination. Therefore, since then, gastronomy has an essential role in tourism development (Tovmasyan, 2019). The development of tourism with the performance of gastronomy can have multiple effects that have a positive impact on a destination. In a holistic definition, gastronomy not only discusses the matters of food, but it also covers the cultural, social, cultural heritage, philosophy, history, health, education, ethics, and others. Since any things can be encouraged by the tourism industry (Turgarini et al., 2018), the gastronomy also has the potential to be developed and managed in further. Moreover, due to the strong relationship between tourism and gastronomy are wellconsidered (Kyriakaki et al., 2013), the gastronomic aspect of the destination could be the main motivation for consuming typical foods originating from the concerning area (Medina-Viruel et al., 2019). Therefore, gastronomy is an important part of tourism which is recognized to possess the ability to form an attractive destination image for the development of a tourism destination amid the development of fierce tourism competition (Sahin, 2015).

In this study, the researcher wants to discuss and present 'Lodho Ayam Kampung' as an element and gastronomical tourism attraction in the Trenggalek region. Trenggalek itself is an area located on the coast in the south of East Java Province, with administrative areas in the form of regencies.

'Lodho Ayam Kampung' is a traditional food from Trenggalek Regency which has spicy dishes characteristics with coconut milk broth. The researcher conducts research related to this cuisine because, in addition to the researcher appraising that this food deserves to be seen as a gastronomic attraction, this food also has its history due to its enduring existences. Thus, some aspects are also feasible and included in the scope of the study of gastronomy. Also, since food is an important aspect that can be experienced by tourists, and in addition to the problem of presentation, taste and value in enjoying a destination (Turgarini et al., 2018), then a potential regard could be developed to enrich the local tourism element.
The researcher has not found any research paper within the scope of tourism, related to 'Lodho Ayam Kampung' with a gastronomic and tourism perspective which aims to present the potential of gastronomy and discuss 'Lodho Ayam Kampung' in gastronomy studies. Therefore, this study aims to fill the research gap. Hence, specifically, the purpose of this research is to present 'Lodho Ayam Kampung' as a tourist attraction of Trenggalek Regency in a gastronomy perspective and to find out the intricates issues regarding 'Lodho Ayam Kampung'.

\section{Literature Review}

\subsection{Cultural-gastronomy}

Gastronomy is something could be perceived as a procedure, instructions, methods related to food. Therefore, culture and gastronomy have attachments that cannot be separated because both are important aspects of gastronomy. It can be said that due to the procedures, instructions, and methods form a cultural concept that exists in society. Gastronomy encompasses the concept of the authenticity of a destination's culture through awareness of the local community's cultural heritage. The authenticity of a civilized destination mobilizes and influences the tourism experience, and forms a new experience, distinctiveness, differences that symbolize a destination (Seyfi et al., 2020).

Gastronomy itself can be recognized as a means in cultural-tourism to find out the habits and lifestyles of people in a destination that represents gastronomic aspects such as local culture through experiences while savouring the taste of regional cuisine (Berbel-Pineda et al., 2019). Therefore, the purpose of tasting local products and food can be defined to relate to the local community and their culture (Zamparini, 2018). Moreover, gastronomy also plays an important role in the preservation of food and beverages which as an element of culturalheritage (Budiningtyas \& Turgarini, 2019).

The idea of local food that reflects culture is well known because each region has a culture and its special food that symbolizes the area (Björk \& Kauppinen- Räisänen, 2016). Additionally, previous studies (Fusté-Forné, 2019) also imply that gastronomy is a tourism product that has an important impact in conducting the value of an area, characteristics, and carrying the authenticity of culture in the place where the culture is introduced. Further, on the concept of gastronomy, Sari et al., (2019) conveyed comprehensively that 
an attempt brought out by the community by producing food through maintaining the recipes, procedures, and raw materials inherited from the ancestors was very valuable and can make a good consequence for tourists.

\subsection{Gastronomic-destination development \\ Since gastronomy has an important role}

in tourism promotion because it can fulfil what is needed by the tourism segment (BalderasCejudo et al., 2019), in the interest of developing a destination, the specific scope of gastronomy such as food also has an important role that cannot be underestimated for its role. This is due to the relationship and attachment that is built between food, society and the area (Fusté- Forné, 2019). This is also reinforced by previous studies (Gordin et al., 2016) which communicate that gastronomy is a stimulus for a creative process and a stimulus for change into active consumption which was previously only limited to passive.

Gastronomic potentiality can be examined and can perform as a factor that holds the development in a destination. Thus, a critical review of the idea of what is the concept of gastronomy in a destination also requires certainty. Besides, the gastronomical aspects of a destination can potentially influence the welfare of tourists since it has a multidimensional element of study (Björk \& Kauppinen-Räisänen,2017).

\section{Materials and Methods}

Due to the aim of this study is to present an ethnic cuisine as a gastronomic tourism attraction in an area (Trenggalek Regency) and explore gastronomic aspects in an area regarding cuisine, this research uses qualitative-descriptive research methods.

The data collection method uses in- depth interview technique. The researcher conducted in-depth interviews with five respondents. These five respondents are the makers of 'Lodho Ayam Kampung' which the researcher knows has existed for a long time. This also as suggested by previous study (Mareth \& Turgarini, 2019) that takes the well-known restaurant (in this case the 'Lodho' maker) that has long standing and has the values of local wisdom as research objects. The point is, intersubjectively, the respondents are people who have been known for making
'Lodho Ayam Kampung' by the surrounding community.

When conducting in-depth interviews, the researcher explained the purpose and objectives of the interview and this research. Also, the researcher explained in general about the gastronomic subject to be investigated. The researcher did not explain specifically and in detail to create natural interview situations. It was only at the end of the interview session, the researcher explained gastronomy in a specific way, to obtain a comprehensive answer from the

respondent regarding the last question of $\mathbf{C 1}$ (Table 1, Appendix A), the respondent's response regarding the making of 'Lodho Ayan Kampung' as a gastronomic tourism attraction in Trenggalek Regency, East Java. Besides, when conducting research, the researcher asks to take part and involve in the making process. This is arranged so that the researcher can observe and study the phenomena more deeply while observing aspects of gastronomy during the research process. The interview process with each respondent takes from 1 to 2.5 hours.

Furthermore, the researcher has made the interview guidelines by writing down the gastronomic aspects to be studied and a list of questions for the respondents that can be seen in Table 1 (Appendix A). Nevertheless, this list of questions is not a standard and patent question. This is because the study of history, philosophy, and social is complex. Thus, answers and explanations that fit the context, will be included in the relevant data categories and groups.

\section{Results and Discussion}

\subsection{Result}

The researcher collects and presents data from respondents who have been interviewed. The detailed presentation can be seen in Table 2 (Appendix B). Besides, the researcher also added a brief description of the results of interviews with respondents in the form of narratives in the next section below.

\subsubsection{Respondent 1; Mrs. Nuryatim (Lodho Ayam Kampung Ibu Sami as brand) \\ 'Lodho Ayam Kampung' Ibu Sami is located in Tapan, Karangan. 'Lodho' makers were interviewed by the researcher named Mrs. Nuryatim by using the name Mrs. Sami as a brand. Mrs Sami, herself is the respondent's mother-in-law.}


Mrs. Nuryatim has been making 'Lodho Ayam Kampung' since 1992. Mrs. Nuryatim knows the recipes from her biological parents, where they are also sellers of 'Lodho Ayam Kampung'. Accordingly, if examined further, this family business has existed for generations (before 1992). However, based on information from Mrs. Nuryatim, the researcher wrote the beginning of the length of time the respondent made 'Lodho Ayam Kampung' in this article since 1992.

Mrs. Nuryatim herself is the 2nd generation in her family who made 'Lodho'. The motivation of respondents to make and sell 'Lodho' itself is as a livelihood. Hence, in addition to the respondent herself acknowledging that the benefits of this cuisine as for making a living, 'Lodho' also helped strengthen the social relations of the respondent's family. This is also due to the involvements of other familiy members, 'Lodho' itself is used as offerings for traditional ceremonies so that many people come and know the respondents.

\subsubsection{Respondent 2; Mr Ayub (Lodho Ayam Kampung Pak Yusuf as brand)}

'Lodho Ayam Kampung Pak Yusuf' is located at Jalan Raya Kedunglurah, Brangkah Wetan, Kedunglurah, Kec. Pogalan, Trenggalek Regency, East Java. Pak Yusuf, who is the father of the respondent, has been making and peddling 'Lodho Ayam Kampung' since 1987. The recipe was inherited from generation to generation and from the surrounding environment.

The respondent said that at first his father (Pak Yusuf) made Lodho because he saw the enthusiasm of the surrounding community towards 'Lodho' as offerings for traditional ceremonies. Because no one had sold it before, Pak Yusuf (a pioneer) made Lodho and sold it to the community to be used as a staple for traditional ceremonies. So, it can be found that the motivation to make and sell 'Lodho' is to provide Lodho as an offering to keep the cultural.

\subsubsection{Respondent 3; Mrs. Mursinah (Lodho Maker)}

Mrs. Mursinah's home is located in Pakel

Sub-village, Pucanganak Village, Tugu District, Trenggalek Regency, East Java. The respondent (Mrs. Mursinah) has been making 'Lodho' since 1989.

In the beginning, when the respondent was a teenager, the respondent joined the cooking activities carried out by his family. In early times, Ibu Mursinah's family made 'Lodho' specifically for family events and used as offerings or main dishes at traditional-ceremonies. Thereupon, the respondents also mastered how to cook 'Lodho Ayam Kampung' and also made food as offerings and main dishes for traditional- ceremonies for their own families and the community in the surrounding villages. Thus, the recipe for 'Lodho Ayam Kampung' obtained by the respondent is a hereditary recipe from his predecessors.

\subsubsection{Respondent 4; Mrs Supartini ('Warung Pojok Timur')}

Mrs Supartini's food stall is called 'Warung Pojok Timur' located at RT 09 RW 02, Dongko Village, Dongko sub-district, Trenggalek Regency, East Java. Frankly, Mrs. Supartini's shop has been established for a long time (before 2005). Nevertheless, she started cooking and selling 'Lodho' in 2005. Mrs. Supartini was the only person who sold 'Lodho' on a large scale in Dongko sub-district. In the beginning, Mrs Supartini made 'Lodho Ayam Kampung' due to her hobby regarding cookery. Mrs. Supartini was the first to sell 'Lodho' on a large scale in her shop in Dongko sub-district, Trenggalek Regency. Since no one has sold 'Lodho' in Dongko subdistrict, later Mrs. Supartini saw an opportunity, and she began to make Lodho 'intensely for business. In addition to on-site and takeaway consumption, people order 'Lodho' to Mrs Supartini habitually used for offerings and main dishes at traditional ceremonies, special ceremonies, and holiday events.

Apart from being a subsistence of life, 'Lodho Ayam Kampung' also provides its benefits for the respondent. 'Lodho' makes the respondent know and be known by many people. Cooking 'Lodho' as a hobby, for pleasure and can bring happiness / Self- fulfilment for respondents, as well as building good social interaction and adding value to the lives of the respondent.

\subsubsection{Responden 5; Mrs. Sileh (DK Lodho as Brand)}

The place where Mrs. Sileh produces and sells 'Lodho Ayam Kampung' established in Pogalan Village, Trenggalek sub-district, Trenggalek Regency. Mrs Sileh has been making and peddling Lodho since 1998. In the beginning, Mrs Sileh made an experiment by testing Lodho 
recipes. Then people became interested in 'Lodho Ayam Kampung' made by Mrs Sileh. Thus, Mrs Sileh continues to make and sell Lodho on a larger scale. Mrs Sileh's motivation to make and sell 'Lodho' is for herself and her family livelihood. Due to the absence of "Lodho Ayam Kampung' seller before, Mrs Sileh saw this as good momentum and took the opportunity. Also, Mrs. Sileh acknowledged that preserving 'Lodho' also motivated her to continue making 'Lodho Ayam Kampung'. Mrs. Sileh got the recipe from the surrounding environment. For the ingredients in their environment itself is inherited in the surrounding population for generations.

\subsection{Gastronomical aspect of 'Lodho Ayam Kampung'}

If explored more deeply, 'Lodho Ayam Kampung' actually has gastronomic aspects which, if explored for its potential, can be used as a gastronomic tourism attraction in Trenggalek Regency. From the results of interviews conducted by the researcher with the respondents, it can be concluded that 'Lodho' is a dish that has existed since the immemorial time. This is reinforced by respondents' answers when the researcher asks questions A2 and A4 (Appendix B, section $\mathbf{A})$, that recipes are obtained from parents, grandparents, or even way long before them. Accordingly, if interpreted implicitly, the answers of these respondents can be admitted that the recipe is inherited from generation to generation. Admittedly, the words 'Lodho' which refer to culinary and food with the chicken dish are found several times in Serat Centhini (P. Sunjata et al., 2014). Serat Centhini itself is a historical narrative consisting of 12 volumes written by Pakubuwono V, a Surakarta Sunanate king along with his three servants. Besides, the Regency of Trenggalek itself once entered the territory of the Regent of Ponorogo, where Ponogoro itself was the territory of the Surakarta Sunanate between 1755 and 1830 (Pemerintah Kabupaten Trenggalek, 2020). Accordingly, the writer interprets that
'Lodho' cuisine indeed have been around since immemorial time. Before that, the respondent number two even said that 'Lodho' was a legacy from the Majapahit kingdom, where the chicken was a special menu originating from the kingdom and spread to the people from generation to generation into offerings and main dishes at traditional ceremonies. This could be true considering the Suarakarta Sunanate itself is a descendant of the Mataram civilization, and Mataram itself is the descendant of the Majapahit civilization (Olthof, 2008). In this case, the Mataram civilization has a fairly fundamental role in establishing and distributing 'Lodho' cuisine in Trenggalek Regency. However, deep approach research is needed in the future to ensure the validity of this history. This is important for the researcher to communicate as an additional insight to attain a harmonious narrative in this article. Moreover, culture, customs, traditions and history are also studies of gastronomic tourism studies.

Besides possessing a historical value that it is worthy for further attention and research, "Lodho Ayam Kampung" also has its role, as well as delivering advantages to the community in Trenggalek Regency. Until recently, culinary heritage is still continuously preserved by those who have high dedication to the cultural heritage of ancestors. This can be seen from the application of 'Lodho Ayam Kampung' as offerings and main dishes for local traditional ceremonies and events that bring special value to the community such as birthday celebrations, weddings, and other thanksgiving ceremonies. One of the sacred events that make this dish as an offering and main dish is the annual jubilee celebration of the district of Trenggalek, which is filled with a series of Javanese traditional ceremonies that are rich of philosophical values.

'Lodho Ayam Kampung' also contributes immeasurable goods to the community. This cuisine has played a role for the makers of 'Lodho' in connecting their lives being. Holding a bridge of welfare between the makers of 'Lodho' and consumers. Also, this cuisine has become a positive impact on the social aspects of society. 'Lodho' became a unifier for all strata of society because it was always offered at traditional events where people are gathered. In a more complex extent, 'Lodho' bridges family relations between entities, strengthens social relations, brings empathy, and becomes a means for the deep sense 
of true family relationships.

'Lodho' has become an identity for the community of Trenggalek Regency. The existence of the dish and recipe that have been present for hundreds of years also immersed in the character of complete communityconsciousness. The philosophical value constructed holistically regarding 'Lodho' has been defined and flowed in the social consciousness of the personalities of Trenggalek Regency. As long as its existence is presented in society for hundreds of years, during that time, the power of culture and the 'fruit of life' is also carried in it as well. Hence that the value is improving.

What has been said above are gastronomical aspects of 'Lodho Ayam Kampung' that cannot be overlooked because it binds the consciousness among the community, cultural values, philosophical values, welfare that flows in every beat of the soul of the people in Trenggalek Regency. 'Lodho Ayam Kampung' bridges them with philosophical energies between their's and their predecessors' consciousness. A product of civilization which is also an intangible cultural heritage has been providing energy to the community for hundreds of years. The community feels full, because of the philosophical beats and well-being that they have experienced because they always give thanks to the universe. This is also in ine with the value carried by 'Lodho Ayam Kampung' as an offering, which is an expression of gratitude to The Creator of Life for blessings, health, and sustenance that goes beyond what is thought by humans. That is the philosophical value.

\subsection{Presenting 'Lodho Ayam Kampung' as gastronomic tourism attraction}

Presenting 'Lodho Kampung Ayam' as a gastronomical tourism attraction in Trenggalek Regency also means having to fully understand the gastronomic aspects and steps to explore other gastronomic potentials related to the cuisine and place in further. The development of gastronomical tourism attraction can suitably have a positive effect on a destination and can maintain a cultural heritage in the destination. Aforementioned is the first essential thing to be emphasized. Due to the gastronomic aspects of 'Lodho Ayam Kampung' are historical and philosophical values, there should be a full concentration among things that can help package the gastronomic concept of 'Lodho Ayam Kampung' as a whole. Gastronomy can also be very useful due to its role in preserving and disseminating the gastronomic aspects themselves that exist in the cuisine. This happens because when gastronomic tourism takes place, the interaction will automatically transpire between 'Lodho' makers and tourists. Furthermore, this interaction as a process of sending knowledge and philosophical values regarding 'Lodho Ayam Kampung', also the role of this dish itself in the community can also be conveyed explicitly.

Also, growing insight into 'Lodho' makers is recognized to be very significant. Aforementioned is a matter thing because 'Lodho' makers are the forefront in gastronomic tourism interactions between tourists and the representation of the local community. Giving adequate penetration into gastronomic tourism to 'Lodho' makers and policymakers will be followed by harmonious tourism development in development trajectory.

As far as the researcher has demonstrated above, 'Lodho Ayam Kampung' possesses several gastronomical aspects that cannot be overlooked. Commencing from philosophies, societies, traditions, and historical narratives that are rich with immeasurable value. Hundreds of years of Javanese civilization are contained in a dish that has become an icon in Trenggalek Regency, as well as its presence and value has sunk and swum in the communal consciousness. These are gastronomical aspects that need to be explored its potentiality, and with good management, then gastronomic tourism in Trenggalek Regency regarding 'Lodho Ayam Kampung' will undoubtedly follow.

Following conducting research, observation, and carrying in-depth interviews, the researcher saw a bunch of potential regarding gastronomic tourism about 'Lodho Ayam Kampung' in Trenggalek Regency. When conducting research, the researcher positioned himself as a tourist who is eager for gastronomic tourism. This kind of issues should be concerned by other tourists in general, both domestic and foreign tourists. This experience must be conveyed so that tourists who come to this area not only know about culinary, which only knows about consuming and then going for their home. But also, with the existence of gastronomic tourism, tourists can get knowledge, as well as gastronomic aspects that exist in 'Lodho Ayam Kampung', and can be understood in complete notion. By conveying this 
kind of experience, tourists can feel adequate and broaden their horizons. In fact, in a deeper philosophical concept, tourists may sink between the consciousness of the surrounding community and the erudite value of the 'Lodho' can be brought even after carrying out tourism activities.

Presenting gastronomical aspects also means delivering in-situ experiences for tourists. For instance, when taking a gastronomic tour, tourists can follow the process of making 'Lodho Ayam Kampung'. This is what distinguishes gastronomy from common culinary tourism. Tourists can follow the cooking process of the chicken from the start as seen in figure 1 (Appendix C), where the initial cooking stage after the chicken slaughter takes place. Likewise, tourists can find out what is the spices are used to cook 'Lodho Ayam Kampung' (Figure 2, Appendix C). All of the 'Lodho' makers who have been interviewed by the authors willingly share their recipes. Similarly, when asked about the gastronomic tourists who might also ask ingredients for cooking later, the respondents said that they would explain gladly because they thought that knowledge should be communicated . Furthermore, tourists can see the process of roasting the chickens that have been bent and stabbed with bamboo (Figure 3, Appendix C). Roasting the chicken is the first ripening stage in cooking 'Lodho Ayam Kampung'. Tourists can interact with the 'Lodho' maker and exchange knowledge, stories, and experiences (Figure 4, Appendix C). This is the hospitality that must be maintained by the forefront of gastronomic tourism for 'Lodho Ayam Kampung' to develop gastronomic tourism in Trenggalek Regency going ahead. The next step in cooking 'Lodho' is to boil it in the 'Lodho' soup that has been cooked with herbs (Figure 5, Appendix C). The duration of boiling the chicken in this stage depends on the 'Lodho' maker, but the estimated of the boiling process takes about 45 minutes to 1 hour. Until the final stage of cooking, tourists can find out the presentation suggestions of 'Lodho Ayam
Kampung ' in Trenggalek Regency (Figure 6, Appendix C), namely 'Lodho Ayam Kampung ', ' Lodho ' broth/soup, and 'urap-urap' (traditional Javanese salad made from boiled vegetables, and served with grated coconut that has been given a special spice), and rice.

Transferring experience to tourists with good hospitality will make the tourism experience inherent in the mindfulness of tourists. This should be an important consideration in developing a tourism destination in further, especially tourism development in Trenggalek Regency, East Java.

\section{Conclusions}

The results of this study concluded that the 'Lodho Ayam Kampung' was not only limited to culinary pursuits and used as daily consumption, as well as souvenirs for tourists but also had gastronomical aspects within. The results of interviews conducted by the researcher with the five respondents indicate that 'Lodho Ayam Kampung' has been around for a long time and the recipe has been inherited from generation to generation, both family and predecessors in the neighborhood. This is also supported by a literature review conducted by the researcher on the history linked with 'Lodho Ayam Kampung' and the history of Trenggalek Regency itself.

The findings obtained by the researcher by observing each respondent and their place during the research process have indicated that this 'Lodho Ayam Kampung' has the potential to be promoted as another gastronomical tourism. Besides having a long historical value, 'Lodho Ayam Kampung' also brings benefits and conditions for values for the people in Trenggalek Regency, as well as its role that cannot be separated from the civilization of the people in Trenggalek Regency.

However, not all respondents know specifically about the history of the 'Lodho' recipe itself. This must be built so that the gastronomic tourism in Trenggalek Regency regarding 'Lodho Ayam Kampung' can be achieved. Distribution of knowledge to 'Lodho' makers is very necessary because Lodho makers are the front guard gastronomic tourism 'Lodho Ayam Kampung' which will interact with tourists later. 


\section{Acknowledgment}

The researcher would like to thank the respondents who were willing to provide detailed information, explanations, and experience to the researcher to achieve the objectives of this study. Also appreciating Mrs. Dewi Turgarini as the guider of gastronomy tourism studies, and all those who have helped in this research.

\section{References}

Balderas-Cejudo, A., Patterson, I., \& Leeson, G. W. (2019). Senior Foodies:A developing niche market in gastronomic tourism. International Journal of Gastronomy and Food Science, 16(October 2018), 100152. https://doi.org/10.1016/j.ijgfs.2019.10 0152

Berbel-Pineda, J. M., Palacios-Florencio, B., Ramírez-Hurtado, J. M., \& SantosRoldán, L. (2019). Gastronomic experience as a factor of motivation in the tourist movements. International Journal of Gastronomy and Food Science, 18(July), 100171.

https://doi.org/10.1016/j.ijgfs.2019.10 0171

Björk, P., \& Kauppinen-Räisänen, H. (2016). Local food: a source for destination attraction. International Journal of Contemporary Hospitality

Management. https://doi.org/10.1108/IJCHM-05- 20140214

Björk, P., \& Kauppinen-Räisänen, H. (2017). A destination's gastronomy as a means for holiday well-being. British Food Journal, 119(7), 1578-1591.

https://doi.org/10.1108/BFJ-09-20160394

Budiningtyas, E. S., \& Turgarini, D. (2019). The Reinforcement of Women's Role in Baluwarti as Part of Gastronomic Tourism and Cultural Heritage Preservation. 259(Isot 2018), 87-90. https://doi.org/10.2991/isot- 18.2019.18

Fusté-Forné, F. (2019). Seasonality in food tourism: wild foods in peripheral areas. Tourism Geographies, O(0), 1-21. https://doi.org/10.1080/14616688.201 8.1558453

Gordin, V., Trabskaya, J., \& Zelenskaya, E.
(2016). The role of hotel restaurants in gastronomic place branding. International Journal of Culture, Tourism, and Hospitality Research, 10(1), $81-90$

https://doi.org/10.1108/IJCTHR-05- 2015-0049

Kyriakaki, A., Zagkotsi, S., \& Trihas, N. (2013). Creating authenctic gastronomic experiences for tourists through local agricultural products: The "greek breakfast" project. 1-9. http://tourconf2013.aegean.gr/proceedi ngs/paper90a.pdf

Mareth, A., \& Turgarini, D. (2019). Tourists' Perception on Gastronomic Heritage Restaurant as a Tourist Attraction in The Sukabumi, Indonesia. 259(Isot 2018), $82-86$. https://doi.org/10.2991/isot- 18.2019.17

Medina-Viruel, M. J., Fuentes Jiménez, P. A., Pérez Gálvez, J. C., \& Santa Cruz, F. G. (2019). The Role of Gastronomy in Trips: Types and Motivations. The Journal of Social Sciences Research, 5(512), $1758-1767$.

https://doi.org/10.32861/jssr.512.1758. 1767

Olthof, W. L. (2008). Babad Tanah Jawi; Mulai dari Nabi Adam sampai Tahun 1647 (F. Aning \& A. Yogaswara (eds.); 4th Editio). Penerbit Narasi.

P. Sunjata, W., Sumarno, \& Mumfangati, T. (2014). KULINER JAWA DALAM SERAT CENTHINI. In Вестник Казнму: Vol. №3 (1st editio). Balai Pelestarian Nilai Budaya (BPNB)

Daerah Istimewa Yogyakarta.

Pemerintah Kabupaten Trenggalek. (2020). Sejarah Trenggalek. Sejarah Trenggalek. https://www.trenggalekkab.go.id/menu ?page $=18 \&$ cat $=16$

Sahin, G. G. (2015). Gastronomy Tourism as an Alternative Tourism: An Assessment on the Gastronomy Tourism Potential of Turkey. International Journal of Academic Research in Business and Social $\quad$ Sciences, 5(9), 79105. https://doi.org/10.6007/ijarbss/v5- i9/1816

Sari, P. A., Turgarini, D., \& Handyastuti, I. (2019). Gastronomic Tourism Attractions in the Kapau Village, Agam Regency, West Sumatra. Gastronomy Tourism Journal, 5(2), 29-41.

Seyfi, S., Hall, C. M., \& Rasoolimanesh, S. M. (2020). Exploring memorable cultural tourism experiences. Journal of Heritage Tourism, 15(3), 341-357.https://doi.org/10.1080/1743873X.201 9.1639717

Tovmasyan, G. ,. (2019). Exploring The Role Of Gastronomy In Tourism. SocioEconomic Challenges, 3(3), 30-39. https://doi.org/10.21272/sec.3(3).30- 39.2019 
Turgarini, D., Baiquni, M., \& Harmayani, E. (2018). The Multiplier Effect of Buying Local Gastronomy: Case of Sundanesse Restaurant. E-Journal of Tourism, $5(1), \quad 54$. https://doi.org/10.24922/eot.v5i1.3846 0 Zamparini, L. (2018). The Role of Gastronomy and Typical Foods in the Tourism Experience. 191-202. https://doi.org/10.1007/978-3-319- 751962_11 


\section{Appendix A}

Table 1. Interview guidance.

\begin{tabular}{|c|c|c|c|c|c|}
\hline Sections & & Questions & Indicator & Source & Technique \\
\hline \multirow{5}{*}{$\begin{array}{l}\text { Section A } \\
\text { Historical } \\
\text { aspect, social } \\
\text { aspect and } \\
\text { philosophic al } \\
\text { value of } \\
\text { respondents }\end{array}$} & A1 & $\begin{array}{l}\text { When did you start selling/being } \\
\text { able to cook 'Lodho Ayam } \\
\text { Kampung'? }\end{array}$ & Historical & $\begin{array}{l}\text { Respondent; } \\
\text { 'Lodho Ayam } \\
\text { Kampung' } \\
\text { maker. }\end{array}$ & $\begin{array}{l}\text { In-depth } \\
\text { Interview }\end{array}$ \\
\hline & A2 & $\begin{array}{l}\text { How does the story regarding you } \\
\text { start selling/being able to cook } \\
\text { 'Lodho Ayam Kampung'? }\end{array}$ & $\begin{array}{l}\text { Historical, } \\
\text { social }\end{array}$ & $\begin{array}{l}\text { Respondent; } \\
\text { 'Lodho Ayam } \\
\text { Kampung' } \\
\text { maker. }\end{array}$ & $\begin{array}{l}\text { In-depth } \\
\text { Interview }\end{array}$ \\
\hline & A3 & $\begin{array}{l}\text { What is the motivation that moves } \\
\text { you to sell/know/learn 'Lodho Ayam } \\
\text { Kampung' cuisine/recipe? }\end{array}$ & $\begin{array}{l}\text { Historical, } \\
\text { social, } \\
\text { philosophy }\end{array}$ & $\begin{array}{l}\text { Respondent; } \\
\text { 'Lodho Ayam } \\
\text { Kampung' } \\
\text { maker. }\end{array}$ & $\begin{array}{l}\text { In-depth } \\
\text { Interview }\end{array}$ \\
\hline & A4 & $\begin{array}{l}\text { How do you know the recipe for } \\
\text { 'Lodho Ayam Kampung'? What } \\
\text { generation is it now? }\end{array}$ & $\begin{array}{l}\text { Historical, } \\
\text { tradition, } \\
\text { social }\end{array}$ & $\begin{array}{l}\text { Respondent; } \\
\text { 'Lodho Ayam } \\
\text { Kampung' } \\
\text { maker. }\end{array}$ & $\begin{array}{l}\text { In-depth } \\
\text { Interview }\end{array}$ \\
\hline & A5 & $\begin{array}{l}\text { What are the benefits of 'Lodho } \\
\text { Ayam Kampung' for the } \\
\text { interviewees? }\end{array}$ & $\begin{array}{l}\text { Historical, } \\
\text { social, } \\
\text { tradition, } \\
\text { philosophy }\end{array}$ & $\begin{array}{l}\text { Respondent; } \\
\text { 'Lodho Ayam } \\
\text { Kampung' } \\
\text { maker. }\end{array}$ & $\begin{array}{l}\text { In-depth } \\
\text { Interview }\end{array}$ \\
\hline $\begin{array}{l}\text { Section B } \\
\text { Historical } \\
\text { aspect, social, } \\
\quad \text { and }\end{array}$ & B1 & $\begin{array}{l}\text { Do you know how the history is } \\
\text { regarding the cuisine itself? }\end{array}$ & $\begin{array}{l}\text { Historical, } \\
\text { social, } \\
\text { tradition, } \\
\text { philosophy }\end{array}$ & $\begin{array}{l}\text { Respondent; } \\
\text { 'Lodho Ayam } \\
\text { Kampung' } \\
\text { maker. }\end{array}$ & $\begin{array}{l}\text { In-depth } \\
\text { Interview }\end{array}$ \\
\hline $\begin{array}{l}\text { philosophic al } \\
\text { value of } \\
\text { cuisine }\end{array}$ & B2 & $\begin{array}{l}\text { What is the role of 'Lodho Ayam } \\
\text { Kampung' in the community? }\end{array}$ & $\begin{array}{l}\text { Historical, } \\
\text { social, } \\
\text { tradition, } \\
\text { philosophy }\end{array}$ & $\begin{array}{l}\text { Respondent; } \\
\text { 'Lodho Ayam } \\
\text { Kampung' } \\
\text { maker. }\end{array}$ & $\begin{array}{l}\text { In-depth } \\
\text { Interview }\end{array}$ \\
\hline $\begin{array}{l}\text { Section C } \\
\text { Perception of } \\
\text { Gastronomi } \\
\text { c Tourism }\end{array}$ & C1 & $\begin{array}{l}\text { What are the answer, response, and } \\
\text { suggestion from the interviewees for } \\
\text { gastronomic tourism? }\end{array}$ & $\begin{array}{l}\text { Respondent's } \\
\text { Perspective }\end{array}$ & $\begin{array}{l}\text { Respondent; } \\
\text { 'Lodho Ayam } \\
\text { Kampung' } \\
\text { maker. }\end{array}$ & $\begin{array}{l}\text { In-depth } \\
\text { Interview }\end{array}$ \\
\hline
\end{tabular}




\section{Appendix B}

Table 2. Interview result.

\begin{tabular}{|c|c|c|c|c|}
\hline \multicolumn{2}{|c|}{ Respondents } & \multirow{2}{*}{$\frac{\text { Questions }}{\text { A1 }}$} & Result/answer & \multirow{2}{*}{$\begin{array}{c}\text { Value } \\
\text { Historical }\end{array}$} \\
\hline \multirow[t]{8}{*}{1} & \multirow{8}{*}{$\begin{array}{c}\text { Mrs. } \\
\text { Nuryatim }\end{array}$} & & Since 1992 & \\
\hline & & A2 & $\begin{array}{l}\text { A family business. Taking order from } \\
\text { consumer }\end{array}$ & $\begin{array}{l}\text { Historical, } \\
\text { social }\end{array}$ \\
\hline & & A3 & Livelihood & Social \\
\hline & & A4 & $\begin{array}{l}\text { Respondents know the recipe for 'Lodho Ayam } \\
\text { Kampung' from parents (hereditary). } \\
\text { Now 2nd generation. }\end{array}$ & $\begin{array}{l}\text { Historical, } \\
\text { social, } \\
\text { tradition }\end{array}$ \\
\hline & & A5 & $\begin{array}{l}\text { Make a living, livelihoods, and strengthening } \\
\text { family relationships because all family } \\
\text { members involved in the same business. }\end{array}$ & $\begin{array}{l}\text { Social, } \\
\text { philosophy }\end{array}$ \\
\hline & & B1 & $\begin{array}{l}\text { Respondents did not know the history of the } \\
\text { cuisine itself specifically. }\end{array}$ & - \\
\hline & & B2 & $\begin{array}{l}\text { For offerings and main dishes at traditional } \\
\text { ceremonies. }\end{array}$ & $\begin{array}{l}\text { Historical, } \\
\text { social, } \\
\text { tradition, } \\
\text { philosophy }\end{array}$ \\
\hline & & $\mathrm{C} 1$ & $\begin{array}{l}\text { Respondents assume that this (gastronomy) is } \\
\text { a good thing because for respondents, } \\
\text { delivering knowledge to others is a good } \\
\text { thing. For respondents, if we have experience } \\
\text { and knowledge, it should be delivered, not } \\
\text { buried alone. Respondents voluntarily share } \\
\text { recipes and tell how the cooking process to } \\
\text { anyone who comes. So that cultural heritage } \\
\text { continues. For respondents, knowledge is } \\
\text { something that is not lost if it is inherited. As } \\
\text { offerings and main dishes at traditional } \\
\text { ceremonies. }\end{array}$ & $\begin{array}{l}\text { Historical, } \\
\text { social, } \\
\text { tradition, } \\
\text { philosophy }\end{array}$ \\
\hline \multirow[t]{4}{*}{2} & \multirow[t]{4}{*}{ Mr. Ayub } & A1 & Since 1987 & Historical \\
\hline & & A2 & $\begin{array}{l}\text { In the past, the surrounding community was } \\
\text { enthusiastic about 'Lodho' as an offering of } \\
\text { redemption/salvation, but no one has sold. } \\
\text { Hence, the respondent's father made 'Lodho } \\
\text { Ayam Kampung' and started the business. }\end{array}$ & $\begin{array}{l}\text { Historical, } \\
\text { social, } \\
\text { tradition. }\end{array}$ \\
\hline & & A3 & $\begin{array}{l}\text { To provide the demand of local people who } \\
\text { are enthusiastic about 'Lodho' cuisine as a } \\
\text { traditional ceremonies/slametan's offering. }\end{array}$ & $\begin{array}{l}\text { Social, } \\
\text { philosophy }\end{array}$ \\
\hline & & A4 & $\begin{array}{l}\text { The recipe is inherited from generation to } \\
\text { generation. At the beginning of the business, } \\
\text { the pioneers learned the recipe from the } \\
\text { surrounding environment and community. } \\
\text { Now 2nd generation }\end{array}$ & $\begin{array}{l}\text { Historical, } \\
\text { social, } \\
\text { tradition. }\end{array}$ \\
\hline
\end{tabular}




\begin{tabular}{|c|c|c|c|}
\hline Respondents & Questions & Result/answer & Value \\
\hline \multirow{12}{*}{ Mursinah } & A5 & $\begin{array}{l}\text { Make a living, strengthening family bonds, } \\
\text { preserving cultural heritage. }\end{array}$ & $\begin{array}{l}\text { Historical, } \\
\text { social, } \\
\text { tradition, } \\
\text { philosophy }\end{array}$ \\
\hline & B1 & $\begin{array}{l}\text { The origin of the cuisine 'Lodho Ayam } \\
\text { Kampung' is a cultural heritage from the era of } \\
\text { the Majapahit kingdom and as a royal menu. } \\
\text { Spread into regional traditions for traditional } \\
\text { ceremonies/slametan. In old times, the chicken } \\
\text { was a special menu, so that the community made } \\
\text { it as an offering. }\end{array}$ & $\begin{array}{l}\text { Historical, } \\
\text { social, } \\
\text { tradition, } \\
\text { philosophy }\end{array}$ \\
\hline & B2 & $\begin{array}{l}\text { Offerings and main dishes for traditional } \\
\text { ceremonies/inheritances events. }\end{array}$ & $\begin{array}{l}\text { Historical, } \\
\text { social, } \\
\text { tradition, } \\
\text { philosophy }\end{array}$ \\
\hline & $\mathrm{C} 1$ & $\begin{array}{l}\text { Very inspiring } \\
\text { Make people eat more solid and fulfil themselves } \\
\text { Good idea } \\
\text { Need a new notion regarding this tour activity } \\
\text { (Gastronomy) }\end{array}$ & $\begin{array}{l}\text { Social, } \\
\text { philosophy }\end{array}$ \\
\hline & A1 & Since 1989 & Historical \\
\hline & A2 & $\begin{array}{l}\text { In the beginning, the respondent joined the } \\
\text { parents in cooking 'Lodho Ayam Kampung' } \\
\text { which was then used for special occasions } \\
\text { and traditional ceremonies. }\end{array}$ & $\begin{array}{l}\text { Historical, } \\
\text { social, } \\
\text { tradition. }\end{array}$ \\
\hline & A3 & $\begin{array}{l}\text { The respondent said the motivation to makes } \\
\text { 'Lodho Ayam Kampung' is to be used as a dish } \\
\text { for special occasions or traditional ceremonies. }\end{array}$ & $\begin{array}{l}\text { Social, } \\
\text { tradition, }\end{array}$ \\
\hline & A4 & $\begin{array}{l}\text { From the respondent's parents and } \\
\text { grandmothers of which inherited } \\
\text { from generation to generation. }\end{array}$ & $\begin{array}{l}\text { Historical, } \\
\text { social, } \\
\text { tradition. }\end{array}$ \\
\hline & A5 & $\begin{array}{l}\text { The dishes were used to strengthen the family } \\
\text { bonds when gathering at special occasions and } \\
\text { traditional ceremonies }\end{array}$ & $\begin{array}{l}\text { Social, } \\
\text { tradition, } \\
\text { philosophy }\end{array}$ \\
\hline & B1 & $\begin{array}{l}\text { According to the respondent, the recipe comes } \\
\text { from the kingdom in ancient times. }\end{array}$ & $\begin{array}{l}\text { Historical, } \\
\text { tradition }\end{array}$ \\
\hline & B2 & $\begin{array}{l}\text { The dishes were used to strengthen the family } \\
\text { bonds when gathering at special occasions and } \\
\text { traditional ceremonies }\end{array}$ & $\begin{array}{l}\text { Historical, } \\
\text { social, } \\
\text { tradition, } \\
\text { philosophy }\end{array}$ \\
\hline & $\mathrm{C} 1$ & $\begin{array}{l}\text { It's great if tourists want to know about 'Lodho } \\
\text { Ayam Kampung' cuisine to gain knowledge so } \\
\text { that it brings benefits and deliver experiences to } \\
\text { others. }\end{array}$ & $\begin{array}{l}\text { Historical, } \\
\text { social, } \\
\text { tradition, } \\
\text { philosophy }\end{array}$ \\
\hline
\end{tabular}




\begin{tabular}{ccccc}
\hline Respondents & Questions & & Result/answer & Value \\
\hline & A1 & Since 2005 & & Historical
\end{tabular}

4 Mrs.

Supartini
Mrs. Supartini made 'Lodho Ayam Kampung' basically because of her hobby of cooking. Mrs. Supartini was the first to sell 'Lodho' on a large A2 scale in her shop in Dongko sub-district, Trenggalek Regency. Since no one has sold 'Lodho' in Dongko sub- district, then Mrs. Supartini saw this as an

opportunity, and she began to make 'Lodho' intensely for sale and special order. A3 heritage and as a livelihood.

Mrs. Supartini knows the recipe from the

A4 consequences of tasting 'Lodho' from various places.Survey to find recipes and distinguished each 'Lodho' dish she has ever tasted, and to carry out cooking experiments repeatedly. In short, Mrs.. Supartini mastered self-taught cooking 'Lodho AyamKampung'. The benefit of 'Lodho Ayam Kampung' for the respondent is for making a living. 'Lodho' makes the respondent know and be known by A5 many people.

Cooking "Lodho" as a hobby, for pleasure and can bring happiness / self-fulfilment.

Build genuine social interactions and add value to life.

B1

B2

The respondent did not know the history of 'Lodho' itself specifically

For 'selametan'. Gathering event. Traditional ceremonies, 'Celebration'. Holiday event. And as offerings on special occasions

Hopefully, in the future, it can become more advanced. Positively, 'Lodho Ayam Kampung' can still be preserved.

C1 Feel happy if there are tourists who come with a gastronomic tour, so the respondent can always receive critique and advice from tourists for a better future of her cookery.
Social

Social, tradition,

Social

Social, philosophy

Social, tradition

Social, tradition, philosophy 


\begin{tabular}{|c|c|c|c|c|}
\hline \multicolumn{2}{|c|}{ Respondents } & Questions & Result/answer & \multirow{2}{*}{$\begin{array}{c}\text { Value } \\
\text { Historical }\end{array}$} \\
\hline & Mrs. Sileh & A1 & Since 1998 & \\
\hline & & A2 & $\begin{array}{l}\text { In the beginning, there was no 'Lodho Ayam } \\
\text { Kampung' maker in Trenggalek (in the } \\
\text { surrounding area). Later, Mrs. Sileh tried to } \\
\text { make 'Lodho Ayam Kampung' and was in } \\
\text { demand by people. Since then, Mrs. Sileh made } \\
\text { 'Lodho Ayam Kampung' intensely on a larger } \\
\text { scale than the first when she has on trial. }\end{array}$ & $\begin{array}{c}\text { Historical, } \\
\text { social, } \\
\text { tradition. }\end{array}$ \\
\hline & & $\mathrm{A} 3$ & $\begin{array}{l}\text { As livelihood, preserving 'Lodho Ayam } \\
\text { Kampung' }\end{array}$ & $\begin{array}{l}\text { Historical, } \\
\text { social, } \\
\text { tradition, } \\
\text { philosophy }\end{array}$ \\
\hline & & A4 & $\begin{array}{l}\text { The recipe knows from experimenting and } \\
\text { testing repeatedly. The compound is inherited by } \\
\text { the predecessor in the surrounding environment } \\
\text { and community }\end{array}$ & $\begin{array}{c}\text { Historical, } \\
\text { social, } \\
\text { tradition. }\end{array}$ \\
\hline & & A5 & $\begin{array}{l}\text { Livelihood, providing satisfaction because it can } \\
\text { help others by employing people (staff). } \\
\text { Add connections. Well-known by many people. }\end{array}$ & $\begin{array}{c}\text { Social, } \\
\text { philosophy }\end{array}$ \\
\hline & & B1 & $\begin{array}{l}\text { The respondent did not know the history of } \\
\text { 'Lodho' itself specifically }\end{array}$ & - \\
\hline & & B2 & $\begin{array}{l}\text { In addition to daily consumption, 'Lodho' is } \\
\text { utilized as offerings and main dishes for } \\
\text { traditional ceremonies, special events to } \\
\text { celebrate birthdays, and as the main course on } \\
\text { holiday. }\end{array}$ & $\begin{array}{c}\text { Historical, } \\
\text { social, } \\
\text { tradition. }\end{array}$ \\
\hline & & $\mathrm{C} 1$ & $\begin{array}{l}\text { It is okay. It's really good if used as a } \\
\text { gastronomic tourist attraction because it can be } \\
\text { more recognised by many people. }\end{array}$ & $\begin{array}{l}\text { Historical, } \\
\text { social. }\end{array}$ \\
\hline
\end{tabular}




\section{Appendix C. Figures}

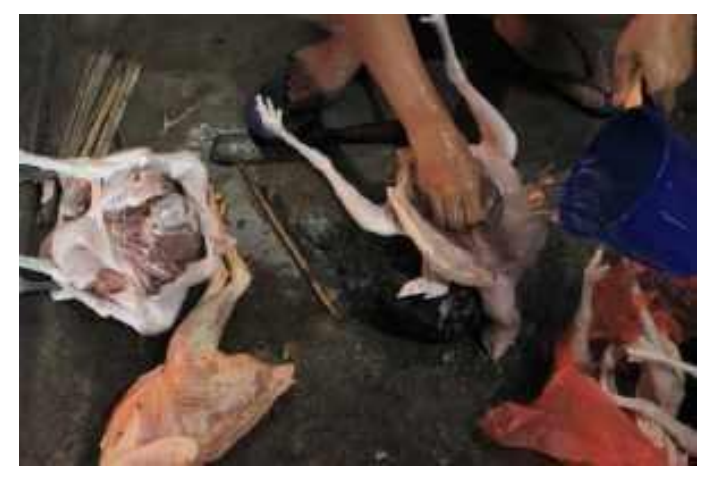

Figure 1

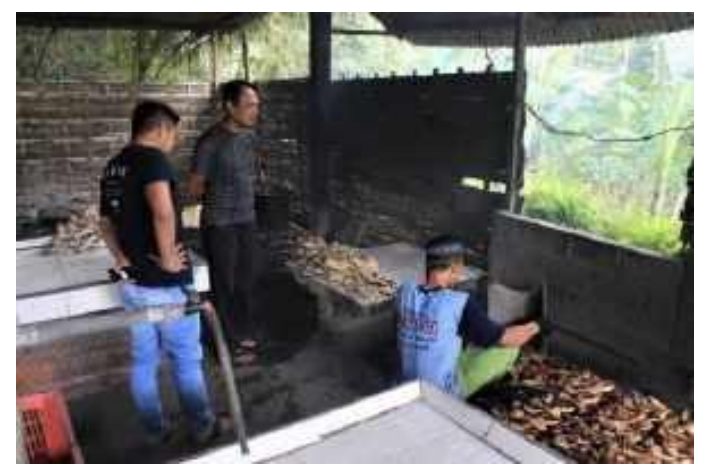

Figure 3

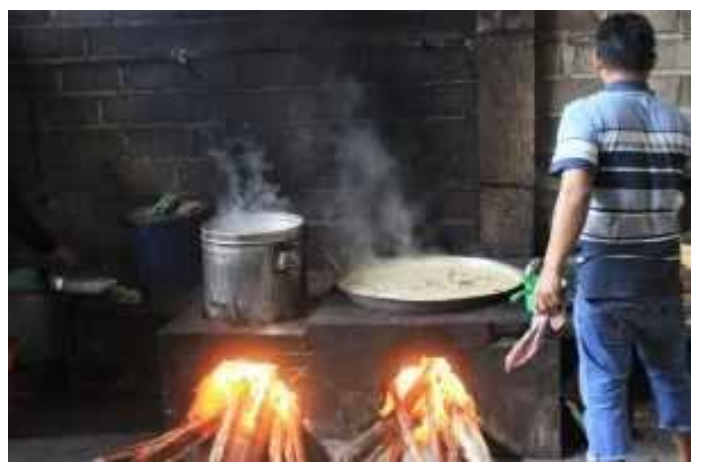

Figure 5

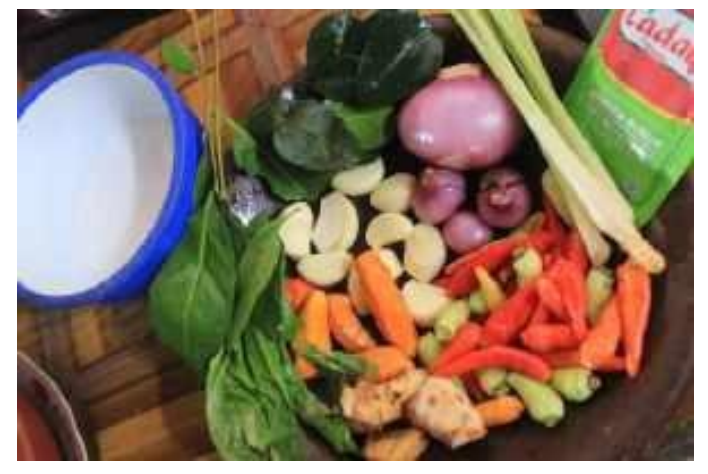

Figure 2

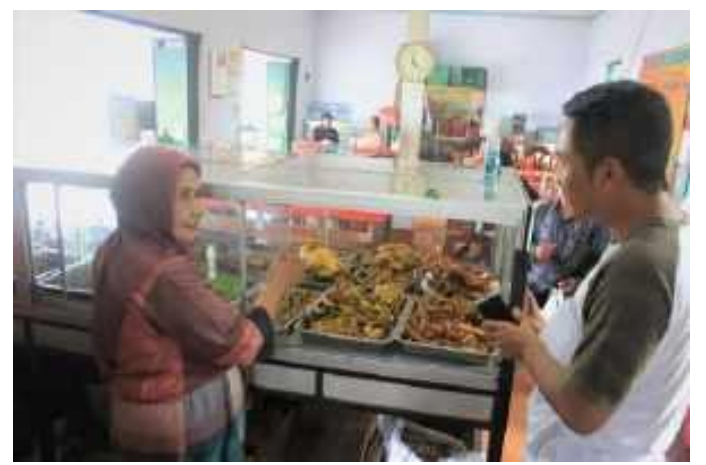

Figure 4

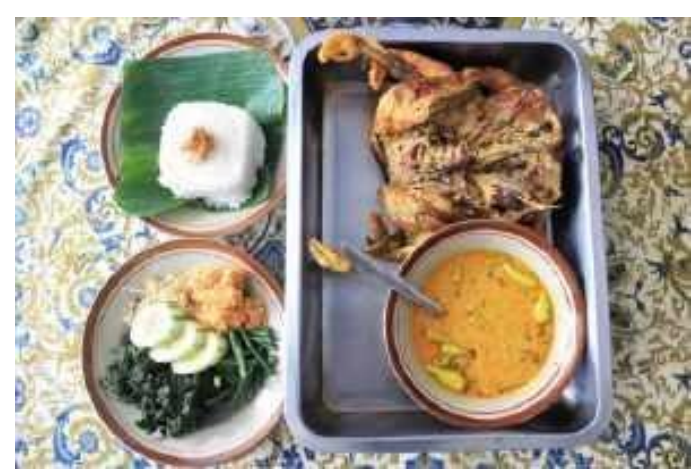

Figure 6

Figure 1. The process of twisting and stabbing a chicken with bamboo; Figure 2. The seasoning of 'Lodho Ayam Kampung '; Figure 3. The method of roasting the chicken ; Figure 4. Interact with the 'Lodho' maker; Figure 5. The next cooking process; Figure 6. Suggestion for Presentation of 'Lodho Ayam Kampung'. 